\title{
Multi-polar trajectories of tourism development within Russian Arctic
}

\author{
Vera Kuklina \\ Laboratory of georesources and political geography \\ George Washington University \\ USA \\ vvkuklina@gmail.com

\section{Vitaly Ruposov} \\ Department of Economics and Management \\ Irkutsk National Research Technical University \\ Russia \\ vitality@mail.ru
}

\author{
Maria Kuklina \\ Department of Management of Industrial Enterprises \\ Irkutsk National Research Technical University \\ Russia \\ kuklina-kmv@yandex.ru \\ Viktor Rogov \\ Department of Management of Industrial Enterprises \\ Irkutsk National Research Technical University \\ Russia \\ rogovvu@mail.ru
}

\author{
Tuyana Bayaskalanova \\ Department of Economics and Management \\ Irkutsk National Research Technical University \\ Russia \\ dama83@mail.ru
}

\begin{abstract}
In difference to other Arctic countries, tourism development in the Arctic zone of Russia remains understudied. One of the problems that the researchers of the Russian Arctic face is the limited availability of the publicly accessible statistical data. Official statistics often cannot catch up with fast speed changes in the Arctic communities. While several case studies have been conducted with the use of qualitative methods for the analysis of tourism development, the knowledge gap exists in quantitative estimations of the phenomenon. Meanwhile, occupation of the one-third of the Arctic territory, concentration of endemic wildlife species, preserved unique Arctic cultures, and improvements in transportation accessibility, make the area highly attractive for tourists. In order to receive more adjusted information on the development of tourist infrastructure, the authors combined analysis of secondary data taken from the previous studies and Russian Committee of Statistics with the Internet tourist resources available in Russian (tourist sites). Based on analysis of available information, the authors distinguished three zones differing in the prospects and scale of the development of tourism infrastructure: European, Siberian, and Far Eastern. While the Russian Arctic has a lot of specific advantages and disadvantages for the tourism development in comparison with other Arctic countries, the interregional contrasts in economies, natural conditions and transportation access are also highly important for understanding different trajectories of tourism development.
\end{abstract} Arctic

Keywords-tourism infrastructure; local communities; Russian

\section{INTRODUCTION}

The Arctic with its unique climate, landscapes, and unique cultures attracts the growing number of tourists. Development of the infrastructure is one of the crucial bases for the tourism advancement there. With the climate change and consequent improvement in maritime accessibility, the researchers note an increase in cruise tourism in Greenland, Alaska, Canada, and Norway [1]. Moreover, proliferation of modern all-terrain and 4WD motorized vehicles in remote parts of the world imposes less stringent requirements on road construction and maintenance [2]. However, the transportation scheme remains difficult for the tourism development in the Arctic that leads to situation where only large-scale enterprises are able to invest significant resources in the tourist business.

From the policy maker's point of view, tourism development is perceived as one of the ways of diversification of local and regional economies [1, 3], and even radical change of local economy. Contribution of tourism to social and economic development in some countries has proved its ability to substantially shape relations within local communities and their dynamics [4]. Particularly, traditional arts and crafts can also benefit from tourism development [1]. While the examples of one or another kind of tourism development are found in many regions of the Arctic, the cases of radical change are less known. Usually it happens when community is not able to conduct previous activities, as was the case of fishing community of Húsavík, Iceland, that turned itself into a tourist destination for whale-watching after revocation of cod-fishing quotas and a moratorium on whaling were imposed at the international level [5]. However, the example is rather an exclusion than a general trend.

Another dimension of tourism development is related to a recreational role of formerly traditional and subsistence activities, such as hunting, fishing, reindeer herding, berry- 
picking etc. There is almost no statistical estimation on how widespread such phenomenon is. However, the potential risks of conflicts between tourism development and traditional styles of life of local communities have to be taken into account $[6,7]$.

About one-third of the Arctic territories lays within Russian borders, and similar issues of all Arctic countries are shared, such as harsh climate conditions, need in diversification of economy and preservation of indigenous cultures and wildlife, very vulnerable landscapes and ecosystems. However, there are very few studies about Arctic tourism development in Russia. Meanwhile increasing use of the Northern Sea Route, and interest in Arctic cultures make the prospects of tourism development more evident.

In the article, the authors emphasize importance of understanding of the Russian Arctic as a geographically, culturally and economically diverse region. The differences within the Arctic demand better planning instruments, more adjusted for regional diversities. While the Russian Arctic in general has a lot of specific advantages and disadvantages for the tourism development, uneven development of its regions has resulted in different trajectories of tourism development.

\section{MATERIALS AND METHODS}

As it was noted by numerous researchers, collaboration between local communities and businesses plays crucial role in the Arctic sustainable development [8-10]. Currently the consumption of the tourist products in the Russian Arctic is considered as a "global playground" for wealthy tourists [11] due to the lack of infrastructure.

The peculiarities of the Russian Arctic tourism were reflected in collection of works "Arctic tourism in Russia" [14]. The works conducted by Pashkevich $[11,15]$ give an understanding of the institutional mechanisms of the tourism development in Russia. However, it is difficult to estimate, how widespread the phenomena described in their works are.

Despite recent advancement in studies of tourism development in the Arctic, knowledge gap remains in understanding interrelation and interdependence of tourism development with economic, social and cultural wellbeing of Arctic communities, and local environment. Available assessments are based on official data derived from the state statistical data. However, current statistics cannot catch up with rapid changes of the local communities, a widespread phenomenon of "informal economy", and an increasing rate of "sharing economy" [12, 13]. Statistics usually count only those accommodation facilities that have 10 or more beds; as a result, the role of wide-spreading small-size guesthouses, holyday homes and apartments in the tourism development remains underestimated.

In order to receive more adjusted information on the development of tourist infrastructure, the authors combined analysis of secondary data, obtained from the previous studies and the Russian Committee of Statistics, and the Internet tourist resources available in Russian. The information about the tours was obtained from the first lines in the search engine on request (for example, tours in the Murmansk region).
Further, the study has focused on one of the main elements of the tourist infrastructure - accommodation facilities. The data from official statistical sources were compared with the most popular Internet resource Booking.com. Although the site is not the only provider of online booking resources, its comparison with the official statistics can give an understanding of general picture.

\section{RESULTS}

\subsection{Background}

The Russian Arctic landscape has some specific traits that differ it from the other Arctic countries and induce particular directions for tourism development. In contrast with the cities of Eastern Europe and southern parts of Russia, in the Arctic there is limited number of the cities able to attract international investments for infrastructural development.

The biggest difference from the other Arctic countries is related to the legacies of the former Soviet planning economy that has included centralized system of decision-making and management, large settlements built for resource exploitation and sea navigation services, and the presence of military regimes and bases. After the end of the soviet planning system, the Arctic experienced large migration outflows. However, Zamyatina \& Yashunsky [16] noted that most of the northern cities keep strong connections with the capital cities and the regions of origins of their current residents. Such strong social networks lead to larger flows of population between the Arctic and other regions of the country, related to the visits of relatives or friends, jobs etc. Also, specific security requirements affect specific visa regime for the international tourists. Finally, according to Pashkevich \& Stjerstrom [11], the infrastructure built for the military purposes, such as airstrips, could be used for the tourism development.

Another difference is related to the specific natural heritage. The Russian Arctic is populated by about $80 \%$ of all species of the entire Arctic wildlife that are extremely vulnerable to various forms of environmental disturbances [17].

The boundaries of the Russian Arctic remain one of the debatable questions. According to the Arctic Human Development Report, the Russian Arctic regions include Murmansk, Karelia, Arkhangelsk, Komi, Yamal-Nenets, Khanty-Mansi, Taimyr and Evenk, Sakha, Magadan, Koryak, Chukotka [1]. However, Pashkevich [11] described tourism institutional structure only in the municipalities above the Arctic Circle and Arctic parts of the Krasnoyarskiicrai and Republic of Komi. Moreover, with administrative reforms the Koryak district is listed as a part of Kamchatsky region. The same definition of Arctic Zone was used in the main policy document, federal program of the Russian Federation "SocialEconomic Development of the Arctic Zone of the Russian Federation for a period till 2020" that was issued in 2014 [18]. Within the program, extension of environmentally nonharmful tourist activities in the Arctic, Arctic tourism development and its promotion at the national and 
international levels are listed among the measures to enhance social-economic development of the Arctic Zone.

The volume of foreign visitors to the Arctic zone of Russia is currently estimated at about one thousand people. Despite the modest number, in terms of the prospects it has a lot of potential. For example, in the summer season of 2014, the "Russian Arctic" was visited by tourists from more than 30 countries with the majority (30\%) from China [19].

According to the Russian Federal Standards [20], different kinds of tours are distinguished:

- Recreational (tours for recreation and medical treatments in resorts);

- Educational (tours with excursions: museum visits, sightseeing, participation in cultural events);

- Business (participation in the workshops, conferences, congresses, fairs, exhibitions etc.);

- Sport (tours for non-professional sports: hiking, horse riding, skiing, mountain climbing, bicycling, diving and other water sporting, fishing, hunting, etc., as well as for participating and attending sports competitions);

- Religious (tours with pilgrimage, participation in religious events, and visits of holy places);

- Tours with other purposes.

Beyond the distinguished kinds of tourism, several researchers have proposed to add event tours, recreational fishing and hunting tours, and eco-tourism as especially relevant for the Arctic, where several specially protected natural reserves have been functioning and attracting tourist attention [21].

Within the Arctic, the distribution of different kinds of tours has its own specifics. Predominantly tourists travel by sea routes and combine cruise with other activities (business, scientific-expedition, ecological, etc.) [22]. The average cruise ships carry about 100 tourists. The second popular kind is the sport tourism that includes sportive fishing, water tourism (rafting), mountaineering, skiing (ski crossing). Groups in such tours are usually small (about 10-20 people).

Beyond conventional forms of transportation, in the Russian Arctic more attention is paid to utilizing other vehicles for tourist transportation: off-road vehicles, submarines, dirigibles, etc. The use of dirigibles is considered as especially worth of attention due to the cost of flying hours is 3 times lower compared to helicopters. The dirigible "Atlant" with carrying capacity up to 16 tons and a range of flight $-2-5$ thousand $\mathrm{km}$ is listed among the most famous designs [23].

\subsection{Tourist zones in the Arctic}

The tourism development in the Arctic is estimated as very costly that would require cooperation of the state and businesses. However, the transportation accessibility, weather and climate conditions, and prospects of development vary across the Russian Arctic, that allows to find three zones distinguished by the tourist development: European, Siberian, and Far Eastern. Besides being different geographically, these zones have various recognition by the federal authorities realized in creation of federal and regional reserves, museums, monuments, and strategies of tourism development.

Special attention is paid to the number of the regional and federal reserves, because they are considered as an infrastructural basis for the development of ecotourism: usually reserves have staff working on development of tourist trails, provision of tourist information, and dissemination of studies conducted within the reserves borders.

\subsubsection{European zone}

The European zone includes Murmansk, Archangelsk, and Komi regions. It is characterized by relatively developed infrastructure, milder weather and climate conditions, and integration with the neighboring Scandinavian tourist routes, business networks, and nature preservation efforts. For example, as a result of trilateral cooperation between Russia, Finland and Norway, the Pasvik-Inari Trilateral Park was created on the territories of these three countries. On a territory of Russia, it is located in Murmansk region.

Within this zone, the most popular tourist sites include the UNESCO cultural and natural heritage site Solovetski islands (Solovki); museums of Sami, Pomor, Nenets cultures; natural reserves; ancient labyrinths, petro glyphs, abandoned military objects, etc. For example, the Archangelsk region alone accounts for more than 10 thousand monuments of architecture, archaeology, history and culture; among them 1,421 have federal significance. It is also connected with the neighbor Republic of Karelia, rich with cultural and natural heritage, including the UNESCO heritage Kizhi Pogost. In sum, there are 15 federal nature reserves and 102 regional nature reserves.

\subsubsection{Siberian zone}

The Siberian zone consists of Yamal-Nenets and Taymyr districts, Arctic parts of Krasnoyarsky crai, and Republic of Sakha (Yakutia). It is oriented more on the protection of natural sites and has the biggest nature reserves, including UNESCO natural heritage site Lena Pillars, Putorana Plateau, Great Arctic, and Taimyr Reserves. However, the total amount of federal reserves is only 11 , and 43 reserves have regional status. This zone is characterized with meager number of sea and airports, remoteness from large ground transportation networks, and more severe weather and climate conditions. Despite its larger size, very few tourist attractions have been designated. Together with Khanty-Mansiyskii district, they form the area dominated by extractive industry that needs diversification of economy and puts some efforts in that direction. The main types of tours in Yakutia are river rafting and fishing, but there are also exclusive offers for tourists, such as search for remains and tusks of mammoths and other extinct animals.

\subsubsection{Far Eastern zone}

The Far Eastern zone is presented by Chukotka autonomous district only. It is characterized by better integration of the tourist routes and business networks with the 
Asian-Pacific countries. It includes the UNESCO heritage site Wrangel Island Reserve, diverse wildlife, archaeological sites, and Transnational Nature Reserve "Beringia" connected with Bering Land Bridge. Although there is only one region, it has 3 federal and 25 regional reserves. Together with Magadan and Kamchatka regions, it forms significant tourist destination.

\subsection{Zonal tours}

The variety and number of tours differ, depending on zones distinguished above, and have strong correlations with the level of infrastructural development. While available natural sites define some specifics of the regions, less attractive but more accessible natural reserves have bigger amount of tours and, consequently, tourists (Table 1).

The Archangelsk region serves as an example of interdependency of tourist infrastructure, regional policy, and the number of tours [23, 24]. It is characterized by positive dynamics of the inbound tourist flows: in $2010-329.6$ thousand people, in 2014 - 390.8 thousand people. During the first 9 months of 2015, the growth of the inbound tourist flow to the Arkhangelsk Region was $11.3 \%$ higher than the same period in 2014. The share of foreign tourists, arriving in the Arkhangelsk region in 2013 and 2014, was $2.4 \%$ and $2.5 \%$, respectively. Among the countries, leading on arrival of their citizens to the Arkhangelsk region, are the countries of the Euro-Arctic region (Norway, Finland and Sweden), Germany, France, Great Britain. Convenient location of the region allows development of interregional and international partnership in the cruise tourism in the Barents region. On the Solovetsky Islands, tourists are offered an extensive excursion program with a visit to the Solovetsky Monastery, the Bolshaya Zayatsky and Muksalma islands. In the summer navigation of 2014, 14 cruise ships visited the unique island of the Solovetsky archipelago - Fr. Anzer, in 2015 - 23, which was a record number for the Arkhangelsk region. In sum, more than 4.5 thousand cruise tourists were served in 2015. Beyond the cruise tourism, there is over a dozen of health resorts, resources for the development of ecological tourism, areas of pilgrim tourism, outdoor activities, extreme tourism (speleological tours, ski trips, reindeer riding, river rafting, snowmobile safaris), youth tourism. Although other Arctic regions have similar recreational resources, their presence in tourism industry is less evident. For example, the Murmansk region has similar transportation infrastructure and is located closer to the Scandinavian countries, but the growth rate of its domestic tourist flow in the last three years averaged $6.4 \%$, the inbound tourist flow $-10.6 \%$. The advantages of Archangelsk region are related to its cultural and ethnic (presence of former Nenets district) and economic diversity.

In order to understand differences between the regions in tourism development more detailed analysis is needed of the history of the regions and relations with the local communities.

\subsection{Tourist accommodations}

According to the official statistical data, the number of accommodation facilities in the Arctic is quite limited. However, the offers in the most popular tourist sites show different picture than the official statistical data (Fig. 1). In contrast with the statistical data, focused on larger facilities (over 10 beds), offers of apartments, holiday homes, and hostels dominate in the Internet.

The more tourism infrastructure is developed in the city, the more offers of apartments can be found in the online booking. For example, in Archangelsk there are only 17 accommodation facilities registered in official statistics, while in the booking.com there are 95 offers, among which $69-$ apartments. In Murmansk - 16 in statistics versus 85 in the Internet, in Kirovsk -11 and 80 respectively. Although the number of facilities is not very big, it shows general involvement of local communities in small tourist business, because there is very small probability that in such settlements the apartments are offered by bigger businesses.

In contrast, industrial cities have more facilities listed in official statistics, than in booking.com. For example, in Vorkuta 36 facilities are registered in official statistics while only 9 - in booking.com; in Mirny - 12 and 4. There is more studies needed for understanding these trends, however, the bigger registration in the official statistics can exemplify orientation of the accommodation facilities on the visitors working in the industrial sector.

\section{DISCUSSION}

For the development of Arctic tourism in Russia, there is, first of all, unique natural and resource potential, many monuments of nature and history, including the ones of the world significance. The development prospects in the nearest future depend on the change in the overall macroeconomic environment for business, search for new non-trivial areas of cooperation between business and the state. Sustainability of these efforts depends on the involvement of local communities in the tourism industry.

Partially domination of apartment accommodation facilities over the hotels reflects current development of "sharing economy", although more qualitative studies are needed to estimate significance of the phenomenon for the local communities.

As a result, the tourism development in the Arctic is characterized as multi-polar not only in a sense of different directions of the development for the European, Siberian, and Far Eastern parts, but also in the increasing contrasts within the cities and between the businesses of different scales. While the large-scale businesses are the most visible players of the tourism market as a marker of globalization, the rented apartments are as globalized, although less visible. 
TABLE I. TOURS OFFERED IN INTERNET AND IN OFFICIAL DOCUMENTS [14]

\begin{tabular}{|c|c|c|c|c|c|c|c|c|c|c|c|}
\hline \multirow{2}{*}{$\begin{array}{l}\text { Kinds of } \\
\text { tours }\end{array}$} & \multicolumn{4}{|c|}{ Western zone } & \multicolumn{4}{|c|}{ Central } & \multicolumn{3}{|c|}{ Eastern } \\
\hline & $\begin{array}{l}\text { Murmans } \\
\text { k region }\end{array}$ & $\begin{array}{c}\text { Archange } \\
\text { lsk } \\
\text { region }^{2}\end{array}$ & $\begin{array}{c}\text { Republic } \\
\text { of } \\
\text { Karelia }^{3}\end{array}$ & $\begin{array}{l}\text { Republic } \\
\text { of Komi }^{4}\end{array}$ & $\begin{array}{l}\text { Yamal- } \\
\text { Nenets } \\
\text { district }^{5}\end{array}$ & $\begin{array}{l}\text { Khanty- } \\
\text { Mancy } \\
\text { district }^{6}\end{array}$ & $\begin{array}{c}\text { Krasno } \\
\text { yarsk } \\
\text { crai }^{7}\end{array}$ & $\begin{array}{c}\text { Republic } \\
\text { of Sakha } \\
\text { (Yakutia) } \\
8\end{array}$ & $\begin{array}{c}\text { Magadan } \\
\text { region' }\end{array}$ & $\begin{array}{l}\text { Chukotka } \\
\text { disctrict }^{10}\end{array}$ & $\begin{array}{l}\text { Kamchatka } \\
\text { region }^{11}\end{array}$ \\
\hline Sight-seeing & 4 & 25 & 2 & 30 & 2 & 11 & 2 & & 1 & - & 3 \\
\hline Ecotours & 3 & 16 & 2 & 4 & 1 & & 1 & & 3 & & 2 \\
\hline Educational & 4 & 25 & & 2 & 2 & 5 & 1 & 2 & 5 & 3 & 6 \\
\hline Event & 4 & 6 & & 1 & 2 & & & 1 & & 3 & \\
\hline $\begin{array}{c}\text { Avia } \\
\text { (helicopters, } \\
\text { paraplanes) }\end{array}$ & 2 & & & & & & & 1 & & & \\
\hline $\begin{array}{l}\text { Recreational } \\
\text { fishing and } \\
\text { hunting }\end{array}$ & 6 & 4 & & 8 & 3 & 6 & 2 & 6 & 4 & & 2 \\
\hline $\begin{array}{l}\text { Sportive } \\
\text { (extreme) }\end{array}$ & 12 & 10 & 9 & 9 & 20 & 8 & 9 & 4 & 6 & 6 & 8 \\
\hline $\begin{array}{l}\text { Ethno- } \\
\text { cultural }\end{array}$ & 6 & 8 & 3 & 2 & 5 & 4 & & 4 & & & 1 \\
\hline Recreational & & & & & & 4 & & & & & 3 \\
\hline Total & 41 & 94 & 16 & 56 & 35 & 38 & 12 & 18 & 19 & 12 & 25 \\
\hline
\end{tabular}

tripadvisor.ru; ${ }^{2}$ russianasha.ru; ${ }^{3}$ http://aviator-tour.com/, http://www.karjalapark.ru, http://www.ice-diving.ru, http://verona-karelia.ru/photoalbum.html, http://aurelia.ru; ${ }^{4}$ visitkomi.ru/, http://shuda-olom.ru; ${ }^{5}$ http://yamaltour.biz/, http://arktida-tur.tiu.ru/, http://arc-tur.ru/, http://www.centrturizm89.ru/, www.yamal.travel.ru; ${ }^{6}$ bron@ugra-service.ru, ugratravel@ugratravel.ru, russkoe86@ rambler.ru; ${ }^{7}$ http://bp-aviok.ru, http://www.alva-tour.ru/,http://discoverytour.ru/; $\quad{ }^{8} \mathrm{http}: / /$ planetyakutia.com/,http://u.visityakutia.com/; $\quad{ }^{9}$ http://www.mirturizma.mdan.ru/,http://taigahunting.ru/; $\quad{ }^{10}$ chukotka-discoveryl.ru www.russiadiscovery.ru; ${ }^{11}$ kamchatkaforyou.com, kamchatkadventures.ru/. 


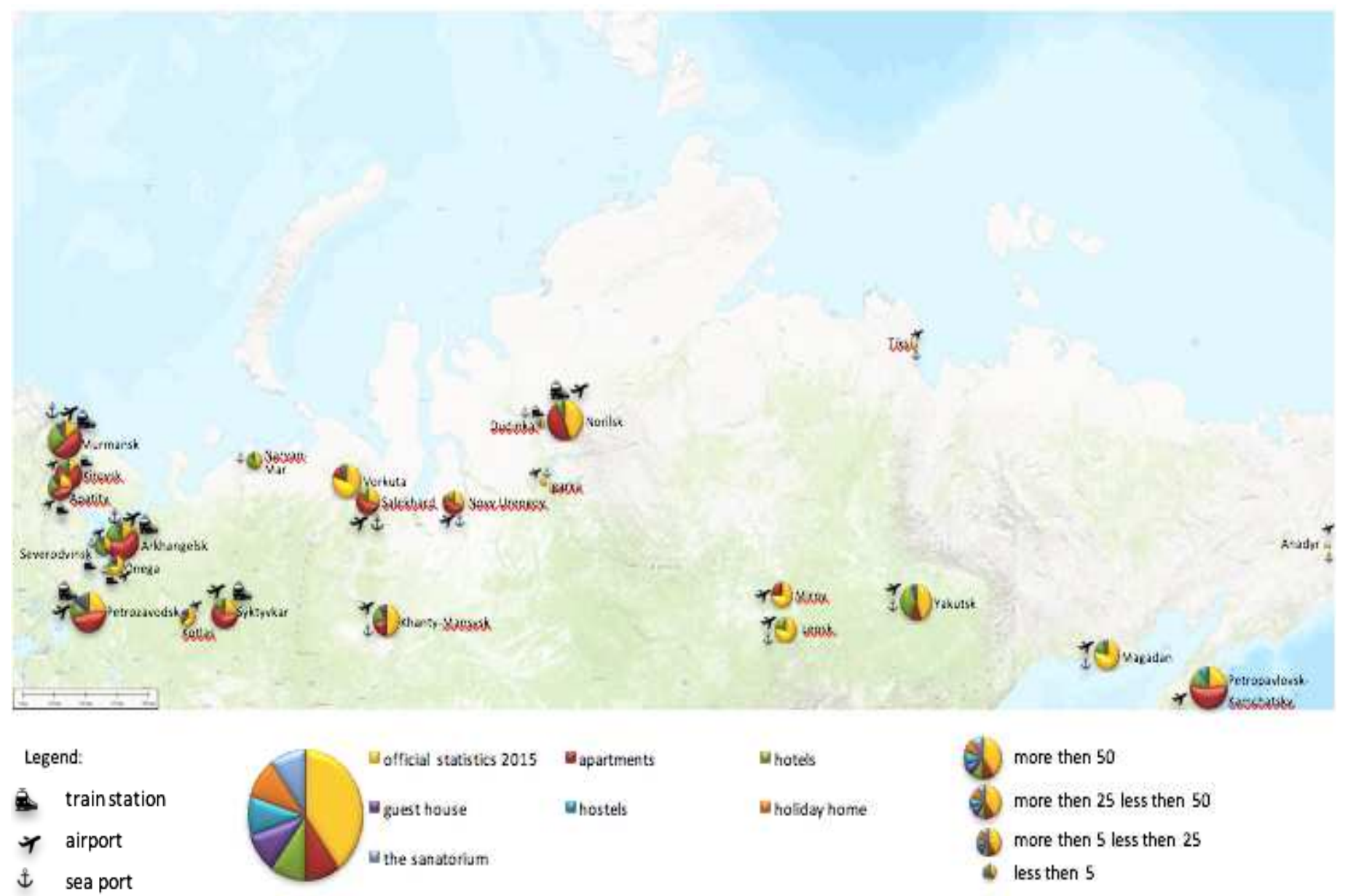

Fig. 1. Accommodation and transportation infrastructure of the main Arctic cities

\section{Acknowledgments}

The reported study was funded by RFBR according to the research project №16-33-01189(a2).

\section{References}

[1] J. Larsen, G. \& Fondahl, Arctic Human Development Report: Regional Processes and Global Linkages. Copenhagen: Nordic Council of Ministers, 2015.

[2] A.J. Taylor, D. Carson, "Four wheel drive tourism and economic development opportunities for remote Australia", Tourismos: An international multidisciplinary journal of tourism, vol. 3(2), pp. 69-85, 2010.

[3] A. Lorentzen, The development of the periphery in the experience economy. Regional Development in Northern Europe: Peripherality, Marginality and Border Issues. New York: Routledge, 2012.

[4] F. Ginny, A. Karlsdóttir, "Social indicators for Arctic tourism: observing trends and assessing data", Polar Geography, vol. 34, pp. 63-86, 2011.

[5] Arctic Council. Arctic Resilience Report. M. Carson and G. Peterson (eds). Stockholm Environment Institute and Stockholm Resilience Centre, Stockholm, 2016, Available online: http://www. arcticcouncil.org/arr.
[6] V.L. Smith, Eskimo tourism: Micro-models and marginal men. Hosts and guests: The anthropology of tourism. Pennsylvania, PA: University of Pennsylvania Press, 1977, pp. 55-82.

[7] S. Nickels, S. Milne, G. Wenzel, "Inuit perceptions of tourism development: The case of Clyde River, Baffin Island", NWT. Études/Inuit/Studies, vol. 15(1), pp. 157-169, 1991.

[8] H. Amundsen, "Differing discourses of development in the Arctic: The case of nature-based tourism in Northern Norway", Northern Review, vol. 35, pp. 125-146. 2012.

[9] B.S.R. Grimwood, N.C. Doubleday, "Illuminating traces: enactments of responsibility in practices of Arctic river tourists and inhabitants", Journal of Ecotourism, vol. 12(2), pp. 53-74, 2013.

[10] E.J. Stewart, D. Draper, "A collaborative approach to understanding local stakeholder perceptions of tourism in Churchill", Manitoba, Canada. Polar Geography, vol. 30(1-2), pp. 7-35, 2014 [Tourism Research in a Changing World, p. 387, 2014].

[11] A. Pashkevich, O. Stjernström, "Making Russian Arctic accessible for tourists: analysis of the institutional barriers", Polar Geography; vol. 282, pp.138-155, 2014, DOI:10.1080/1088937X.2014.919040.

[12] G. Russo, R. Lombardi, S. Mangiagli, "The Tourist Model in the Collaborative Economy: A Modern Approach", International Journal of Business and Management, vol. 7(8), pp. 1-13, 2013.

[13] J. Morgan, "Why The Collaborative Economy Is Changing Everything". Forbes, 2014, Available online: http://www.forbes.com/sites/jacobmorgan/2014/10/16/why-the- 
collaborative-economy-is-changing-everything/\#62096d64fc1d. (accessed 27.01.2016).

[14] Arkticheskijturizm v Rossii; Y.F. Lukin, E.A. Shepelev, Eds. Arkhangel'sk - Sankt-Peterburg, 2016, p. 257.

[15] A. Pashkevich, Tourism development planning and product development in the context of Russian Arctic territories. In: From talk to action: how tourism is changing the polar regions R.H. Lemelin, P. Maher, and D. Liggett, eds. , Ontario: Centre for Northern Studies Press, Lakehead University, 2013, pp. 41-60.

[16] N. Zamyatina, A. Yashunsky, Migration cycles, social capital, and networks: A new way to look at Arctic mobility New Mobilities and Social Changes in Russia's Arctic Regions, London: Routledge, 2017, pp. 59-84. Available online: https://www.routledge.com/NewMobilities-and-Social-Changes-in-Russias-Arctic-

Regions/Laruelle/p/book/9781138191471

[17] M.S. Stishov, Osobo okhranjaemye prirodnye territorii Rossijskoj Arktiki: sovremennoe sostojanie i perspektivy razvitija, avtor-sostavitel', WWF Rossii, 2013.

[18] Postanovleniie Pravitelstva RF ot 24.04.2014 nomer 366, Available online: https://rg.ru/2014/04/24/arktika-site-dok.html (accessed on 29.04.2017).

[19] N.M. Byzova, “Turistskaja privlekatel'nost' arkticheskih ostrovov v Arhangel'skoj oblasti”, Arkticheskijturizm v Rossii Arkhangel'sk Sankt-Peterburg, pp.31-40, 2016 [Arkticheskijturizm v Rossii, p. 257, 2016]

[20] GOST R 50690-2000 Turistskie uslugi. Obshhie trebovanija, Available online: http://docs.cntd.ru/document/1200025205(accessed on 15.04.2017).

[21] E.I. Arsen'eva, A.S. Kuskov, Ekoturistskij potencial osobo ohranjaemyh prirodnyh territoriji problemyj ego ispol'zovanija, Turizm i kul'turnoe nasledie, 3rd Edition. Saratov: SGU, pp. 7-19, 2005.

[22] Dirizhabl' dlya rossijskoj armii postroyat k 2018 godu, Available online:http://politikus.ru/industry/53199-dirizhabl-dlya-rossiyskoyarmii-postroyat-k-2018-godu.html(accessed on 21.04.2017).

[23] L.N. Drachkova, "Prirodno-rekreacionniyi istoriko-kulturniy potensial Rossijskoj Arktiki", Arkticheskijturizm v Rossii Arkhangel'sk — SanktPeterburg, pp.31-40, 2016 [Arkticheskijturizm v Rossii, p. 257, 2016]

[24] M. Lamers, A. Pashkevich, Short-circuiting cruise tourism practices along the Russian Barents Sea coast? The case of Arkhangelsk. Current Issues in Tourism 2015, 2015, Available online: http://dx.doi.org/10.1080/13683500.2015.1092947. 